\title{
Differentiation of Fresh from Frozen Thawed Chevon by Citrate Synthase Enzymatic Assay
}

\section{Gowtham Prasad Bomminayuni ${ }^{1}$, Sanjod Kumar Mendiratta ${ }^{1}$, Suman Talukder $^{1}$, Sagar Chand ${ }^{1}$, Rohit Kumar Jaiswal ${ }^{2 *}$ and Vandita Mishra ${ }^{1}$}

\author{
${ }^{1}$ Division of Livestock Products Technology, Indian Veterinary Research Institute, \\ Izatnagar, Bareilly, Uttar Pradesh-243 122, India \\ ${ }^{2}$ Department of Livestock Products Technology, Bihar Veterinary College, \\ Patna, Bihar-800014, India
}

*Corresponding author

Keywords

Chevon,

longissimusdorsi muscle, Freezethaw cycle, Citrate synthase, meat quality changes

Article Info

Accepted:

18 May 2020 Available Online:

10 June 2020

\section{A B S T R A C T}

The objective of study was to differentiate fresh from frozen-thawed chevon by evaluating citrate synthase enzymatic assay and the effects of repeated freezethaw cycles (0-2) on physico-chemical and microbiological parameters in longissimusdorsi of chevon. The activity of themitochondrial enzyme in meat press juice from fresh and frozen-thawed meat was compared to know the efficacy of these enzymes in differentiating fresh from frozen-thawed meat. Citrate synthase activity had shown more significant change in values of meat press juice of fresh and frozen-thawed chevon. The physico-chemical and microbiological characteristics had also shown good correlation with the activity of enzyme at different stages of freeze-thaw cycles. A significant $(\mathrm{P}<0.05)$ reduction in $\mathrm{pH}$, and water holding capacity; however, a significant increase in TBARS and thawing loss was observed from fresh to $2^{\text {nd }}$ freeze-thaw cycle whereas total plate count showed increasing trend from fresh to $2^{\text {nd }}$ freeze-thaw cycle. Therefore, citrate synthase enzymatic assay could be a suitable method for the differentiation of frozen-thawed from fresh chevon.

\section{Introduction}

Chevon is the most preferred and costliest meat sold in markets of northern India. The meat produced for the domestic market is mainly sold as fresh hot meat. Fresh meat is a perishable commodity with high water activity, unable to maintain its desired sensory and microbial attributes for a longer period of time at room temperature or inside chiller. So, unscrupulous retailers fraudulently mislabel their product, selling frozen-thawed meat as fresh meat for higher profit (Simoniova et al., 2013). Due to increase in incidents of illegal selling of frozen-thawed meat as fresh meat, and in order to protect interest of consumers and domestic meat producers, it is necessary to differentiate fresh from frozen-thawed meat 
(Ballin and Lametsch, 2008).In scarcity of information regarding an effective assay to differentiate between fresh and frozen-thawed meat, this type of marketing or mislabeling generally unnoticed. Several number of methods were proposed based on different principles such as sensory detection, comet assay, enzymatic assay, DNA based assay, visible and near infrared reflectance spectroscopy, nuclear magnetic resonance, bio-imaging and enzymatic methods have been suggested to differentiate fresh and frozen-thawed meat (Ballin and Lametsch, 2008). Amongst all these methods, enzymatic assay has been recommended as the method of choice due to its rapidity and economics.

Enzymes released by damage to cell organelles by ice crystals during repeated freezing and thawing can be used as potential biomarker to differentiate fresh and frozenthawed meat. The enzyme chosen for enzymatic assay must fulfill three requirements i.e. it should be released by freezing and thawing but not by ageing of meat; its total activity should not be decreased markedly during storage of muscle either fresh or frozen and it should be easily detectable in the muscle-press juice (Hamm, 1979).Citrate synthase is a typical intracellular enzyme released after freezing and satisfies the conditions for use as specific markers (Hamm and Gottesmann, 1984).Enzymes released from the ruptured mitochondrial membrane can be detected in exudate released during thawing and nature of meat can then be ascertained through the measurement of enzymatic activity in exudate. The activity of enzyme in frozenthawed meat exudatesis considerably higher than in exudate of fresh meat, which further enhances with each successive freeze-thaw cycle.It is possible to determine its activityof citrate synthase,a specific mitochondrial enzyme in a relatively small amount of exudate $(5 \mu l)$ (Simoniova et al., 2013).Thus, only limited studies have been conducted and no reliable method is available especially for chevon. The present study was carried out to develop rapid and reliable method to distinguish between fresh and frozen-thawed chevon

\section{Materials and Methods}

\section{Sampling}

Chevon longissimusdorsi muscle was procured from Experimental Abattoir of Livestock Products Technology Division, ICAR-Indian Veterinary Research Institute, Izatnagar and local market of Bareilly. The samples were transported to the laboratory in insulated ice-box under controlled conditions and packed in LDPE pouches and subjected to different treatments as per requirement. At $8 \mathrm{hrs}$ of postmortem, each chilled muscle was cut into three pieces with $3.0 \mathrm{~cm}$ thickness, perpendicular to muscle fiber orientation. The first sample was analyzed directly as the control ( 0 cycle). Other two pieces were frozen at $-18 \pm 2^{\circ} \mathrm{C}$ for $48 \mathrm{hrs}$ and these samples were thawed at refrigerated temperature $\left(4 \pm 1^{\circ} \mathrm{C}\right)$ for $12 \mathrm{hrs}$, two cycles of freeze-thaw were carried out to simulate the conditions of fraudulent practices occurring under field conditions. Meat press juice from fresh and frozen-thawed meat after different cycles was collected using compression method (Cheung et al., 2015) (Fig. 1.). The activity/concentration of citrate synthase enzyme was determined in chevon meat press juice.

\section{Collection of meat press juice}

Meat press juice from fresh and frozenthawed meat after different cycles was collected using compression method (Fig. 1.) as described by Cheung et al., (2015). Meat cube was placed inside a plastic bag which was positioned between two Perspex plastic 
plates attached with T-clamp screw. Meat press juice was obtained by exerting a pressure on the plastic bag for five minutes in case of fresh meat sample and two to three minutes for chilled or frozen-thawed samples. The activity/concentration of citrate synthase enzyme was determined in the meat press juice.

\section{Citrate synthase (CS) enzymatic assay}

Citrate synthase enzymatic activity was determined as per the method defined by Simoniova et al., (2013) with suitable alterations. Meat press juice $(0.5-1.0 \mathrm{ml})$ was collected from fresh and frozen-thawed chevon samples using compression method (Cheung et al., 2015). The meat press juice was centrifuged (HERMLE Z32 HK, Germany)at $10,000 \mathrm{rpm}$ for $5 \mathrm{~min}$ at $4^{\circ} \mathrm{C}$ to collect the supernatant and remove insoluble material.5 $\mu \mathrm{l}$ of supernatant was added in to the wells and made the final volume of $50 \mu \mathrm{l}$ using CS Assay buffer. $50 \mu \mathrm{l}$ of the appropriate reaction mix (Table. 1) was added to each of the wells and mixed by pipetting and plate was incubated at $25^{\circ} \mathrm{C}$.

The absorbance was measured at412nm using ELISA plate reader (BIO-RAD, iMark ${ }^{\mathrm{TM}}$ Microplate Reader, Germany)at the initial time and taking measurements at every $5 \mathrm{~min}$ for $20-40 \mathrm{~min}$ while incubating at $25^{\circ} \mathrm{C}$. The final absorbance measurements for calculating the enzyme activity was the penultimate reading or the value before the most active sample is near or exceeds the end of the linear range of the standard curve. The time of the penultimate reading is $\mathrm{T}_{\text {final }}$.

$$
\text { CS Activity (milli unit } / \mu \mathrm{l})=\frac{\mathrm{S}_{\mathrm{a}}}{\text { Reaction Time } \mathrm{S}_{\mathrm{v}}}
$$

Where,

$\mathrm{Sa}=$ Amount of Glutathione (GSH) (nmole) generated in unknown sample well between
$\mathrm{T}_{\text {inital }}$ and $\mathrm{T}_{\text {final }}$ from standard curve

Reaction Time $=\mathrm{T}_{\text {final }}-\mathrm{T}_{\text {initial }}$ (minutes)

$\mathrm{Sv}=$ sample volume $(\mu \mathrm{l})$ added to well

Citrate synthase activity is reported as $\mu \mathrm{mole} / \mathrm{ml} / \mathrm{min}$ or milli unit $/ \mathrm{ml}$ or $\mathrm{mU} / \mathrm{ml}$. One unit of citrate synthase is the amount of enzyme that generates $1.0 \mu$ moles of $\mathrm{CoA}$ per minute at $25^{\circ} \mathrm{C}$ and $\mathrm{pH} 7.2$.

\section{Physico-chemical parameters}

\section{pH measurement}

Muscle $\mathrm{pH}$ value was measured in triplicate according to the method of Trout et al., (1992). Briefly, $5 \mathrm{~g}$ of sample was homogenized (Ultra Turraxmodel T25, Janke and Kenkel, IKA, Germany)at $6000 \mathrm{rpm}$ for $15 \mathrm{~s}$ in $45 \mathrm{ml}$ of distilled water $(\mathrm{pH} \mathrm{7.0)}$. The $\mathrm{pH}$ value of the homogenate was determined with a combined electrode connected to a Hanna pH meter (Hanna 211 Intruments, Italy).

\section{TBARS (2-thio barbituric acid reactive substances) value}

The distillation method of Tarlagdis et al., (1960) was followed to estimate TBARS value.

\section{Water holding capacity (WHC)}

WHC was determined by the method of Li et al., (2012) with slight modifications. Meat sample ( $2 \mathrm{~g}$ ) was kept between two dried Whatman No. 1 filter papers (pre-weighed) and pressure of $343 \mathrm{~N}$ forces was applied for 5 min using a compression instrument (two Perspex plastic plates attached parallel with T-clamp screw, Germany). WHC was calculated as a percentage of weight loss based on measurements before and after 
compression of meat and expressed as:

$$
\mathrm{WHC}(\%)=\frac{(\mathrm{W} 1)-(\mathrm{W} 2)}{\mathrm{W} 1}
$$

Where,

$\mathrm{W} 1=$ Initial weight of sample before application of pressure

W2 = Final weight of sample after application of pressure

\section{Thawing loss}

Thaw loss was determined by method (AOAC, 1995) of weighing fresh, chilled, $1^{\text {st }}$ freeze-thaw and $2^{\text {nd }}$ freeze-thaw samples, before thawing and after thawing. Loss in terms of thawing of the meat samples was calculated by a percentage of weight loss of meat samples before and after thawing.

Thawing loss $(\%)=\frac{(\mathrm{W} 1)-(\mathrm{W} 2)}{\mathrm{W} 1} \times 100$

Where,

W1 = Initial weight of sample before thawing W2 $=$ Final weight of sample after thawing

\section{Microbiological analysis}

\section{Total plate count (TPC)}

The total plate count (TPC) was determined using plate count agar to evaluate the microbiological quality of fresh and frozenthawed chevon meat samples.23.5 g of plate count agar was suspended in 1liter distilled water and boiled the medium to dissolve completely and sterilized the medium by autoclaving at $15 \mathrm{lb}$ pressure at $121^{\circ} \mathrm{C}$ for 15 min. Final $\mathrm{pH}$ of medium was 7.0 \pm 0.2 . Duplicate sets of petri dishes were inoculated aseptically with $1 \mathrm{ml}$ aliquot from appropriate dilutions.
About $20 \mathrm{ml}$ of plate count agar, melted and maintained at $44-46^{\circ} \mathrm{C}$, was poured gently. The plates were incubated at $37 \pm 1^{\circ} \mathrm{C}$ for $48 \mathrm{~h}$. Plates showing 30-300 colonies were selected for counting. The numbers of colonies counted were multiplied with reciprocal of the dilution and expressed the TPC count as $\log _{10} \mathrm{cfu} / \mathrm{g}$.

\section{Results and Discussion}

\section{Citrate synthase (CS) activity}

Citrate synthase activity value measured in exudate released from fresh, $1^{\text {st }}$ freeze-thaw cycle and $2^{\text {nd }}$ freeze-thaw cycle chevon samples were 0.034, 0.165 and $0.345 \mu \mathrm{mol} / \mathrm{ml} / \mathrm{min}$ respectively (Fig. 2). The activity of citrate synthase for fresh chevon samples ranged $0.034 \pm 0.003 \mu \mathrm{mol} / \mathrm{ml} / \mathrm{min}$, while $0.165 \pm 0.004 \mu \mathrm{mol} / \mathrm{ml} / \mathrm{min}$ or more for the frozen-thawed chevon samples. The activity of citrate synthase was higher in exudate from frozen-thawed samples and increased with repeated freezing-thawing. The trend in activity of citrate synthase for chevon with subsequent freeze-thaw cycle was similar to the findings of Pipek et al., (2010) in pork.

Citrate Synthase is mitochondrial specific enzyme to and it is possible to detect the enzymatic activity in a relatively less amount of meat exudate $(5 \mu \mathrm{l})$ (Simoniova et al., 2013). The increase in enzymatic activity is due to action of microorganisms present in the meat and ice crystals formed during freezingthawing which might damage the muscle cells and mitochondrial membrane structure during thawing, and thus the endogenous enzymes could be released into the meat exudate during the storage. The increased activity of enzyme during the storage period at temperatures below freezing point of meat could be due to cell organelles damage caused by the growing of ice crystals during freezing- 
thawing process. Furthermore, at storage period due to temperatures abuse and fluctuations, the ice crystals may grow or shrink subsequently damages the cell cytoskeleton. Thus, damage to mitochondrial membranes has positive and significant correlation with the activity of citrate synthase (Simoniova et al., 2013).

Physico-chemical and microbiological parameters and its correlation with Citrate synthase activity

\section{pH}

The $\mathrm{pH}$ values $(\mathrm{Mean} \pm \mathrm{SE})$ of FM, 1FT and 2FT were $5.93 \pm 0.17,5.76 \pm 0.14$ and $5.41 \pm 0.21$ respectively (Table 2 ), which were decreased significantly $(\mathrm{P}<0.05)$ with the progression of freeze-thaw cycles. Muscle $\mathrm{pH}$ value decreased significantly $(\mathrm{P}<0.05)$ with increase in number of freeze-thaw cycles in chevon. It could be attributed to rapid decline of muscle temperature, and as a result, activities of glycolytic enzymes decreased accompanied by lowered rate of glycolysis (Savell et al., 2005). Leygonie et al., (2011) also reported that the $\mathrm{pH}$ of meat that has been frozen and thawed tends to be lower than prior to freezing. As $\mathrm{pH}$ is a measure of the amount of free hydrogen ions $(\mathrm{H}+)$ in a solution, it is possible that freezing with subsequent exudate production could cause denaturation of buffer proteins, the release of hydrogen ions and a subsequent decrease in $\mathrm{pH}$ (Leygonie et al., 2011). This corroborates with the findings of Qi et al., (2012) for ovine longissmusdorsi muscle, Ali et al., (2015) and Chen et al., (2017) for chicken breast muscle and Cheng et al., (2019) for beef semimembranosus muscle.

\section{TBARS}

TBARS value determines the stability of lipid in meat. Available lipid in meat gets oxidized during storage. There was an increase in TBARS value (Mean \pm SE) of chevon from $0.19 \pm 0.02 \mathrm{mg} \mathrm{MDA} / \mathrm{kg}$ in fresh sample, $0.36 \pm 0.05 \mathrm{mg} \mathrm{MDA} / \mathrm{kg}$ in $1^{\text {st }}$ freeze-thaw cycle, $0.69 \pm 0.03 \mathrm{mg} \mathrm{MDA} / \mathrm{kg}$ in $2^{\text {nd }}$ freezethaw cycle (Table 2). The lipid oxidation was found to be pronounced during repeated freeze-thaw cycles (Xia et al., 2009). It is always concomitant with the degradation of unsaturated fatty acids (Hernandez et al., 1999).

However, lipolysis of phospholipids could occur during subsequent thaw-freeze storage (Saldanha and Bragagnolo, 2008) and result increase in free fatty acids. Lipolytic enzymes were shown to keep active during frozen storage (Hernandez et al., 1999). It was noted freeze-thaw cycles played an essential role in accelerating the oxidation, as the ice crystals had potential to damage the cell structure and subsequent release of certain pro-oxidants viz.oxidative enzymes, haem iron and free radicals for lipid oxidation (Benjakul and Bauer, 2001; Leygonie et al., 2012).

The TBARS observed in this study was comparable with the TBARS of porcine longissmusdorsi (Xia et al., 2009), beef semimebranosus (Cheng et al., 2019) and ovine longissmusdorsi (Qi et al., 2012) muscle during multiple freeze-thaw cycles.

\section{Water holding capacity (WHC)}

Measured values (Mean \pm SE) of WHC in chevon was $54.19 \pm 1.76 \%$ in fresh sample, whereas $42.24 \pm 1.28 \%$ after one freeze-thaw cycle, and increased $(\mathrm{P}<0.05)$ to $31.68 \pm 1.91 \%$ after $2^{\text {nd }}$ freeze-thaw cycle(Table 2). In general, frozen storage with successive freezing-thawing contributes significantly to reduction in the water holding capacity of meat (Vieira et al., 2009). The increase in water loss volume indicated loss of waterholding capacity of the muscle. 
Table.1 Reaction mix

\begin{tabular}{|l|c|c|}
\hline Reagent & Samples $(\boldsymbol{\mu l})$ & Blank \\
\hline CS Assay buffer & $43 \mu \mathrm{l}$ & $45 \mu \mathrm{l}$ \\
\hline CS Developer & $5 \mu \mathrm{l}$ & $5 \mu \mathrm{l}$ \\
\hline CS Substrate Mix & $2 \mu \mathrm{l}$ & - \\
\hline
\end{tabular}

Table.2 Meat quality parameters of chevon longissimusdorsi muscle samples derived from different freeze-thaw cycles (Mean \pm S.E.)

\begin{tabular}{|c|c|c|c|}
\hline Parameter & Fresh meat & $1^{\text {st }}$ Freeze-thaw cycle & $2^{\text {nd }}$ Freeze-thaw cycle \\
\hline \multicolumn{4}{|c|}{ Physico-chemical parameters } \\
\hline pH & $5.93 \pm 0.17^{\mathrm{a}}$ & $5.76 \pm 0.14^{b}$ & $5.41 \pm 0.21^{\mathrm{c}}$ \\
\hline TBARS (mg MDA/kg) & $0.19 \pm 0.02^{\mathrm{a}}$ & $0.36 \pm 0.05^{b}$ & $0.69 \pm 0.03^{\mathrm{c}}$ \\
\hline WHC (\%) & $54.19 \pm 1.76^{\mathrm{a}}$ & $42.24 \pm 1.28^{b}$ & $31.68 \pm 1.91^{\mathrm{c}}$ \\
\hline Thawing loss (\%) & 0 & $11.15 \pm 0.62^{\mathrm{a}}$ & $24.31 \pm 0.84^{\mathrm{b}}$ \\
\hline \multicolumn{4}{|c|}{ Microbiological parameter $\left(\log _{10} \mathrm{cfu} / \mathrm{g}\right)$} \\
\hline Total Plate Count & $4.82 \pm 0.17^{\mathrm{a}}$ & $5.61 \pm 0.22^{b}$ & $6.91 \pm 0.13^{c}$ \\
\hline
\end{tabular}

$\mathrm{n}=6 ; \quad$ Values with different superscripts $(\mathrm{a}, \mathrm{b}, \mathrm{c})$ in the same column are significantly different $(\mathrm{P}<0.05)$

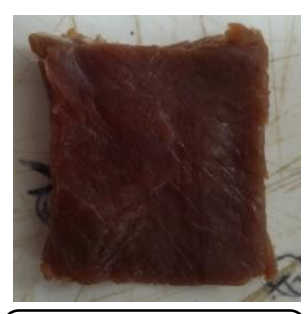

Meat chunk
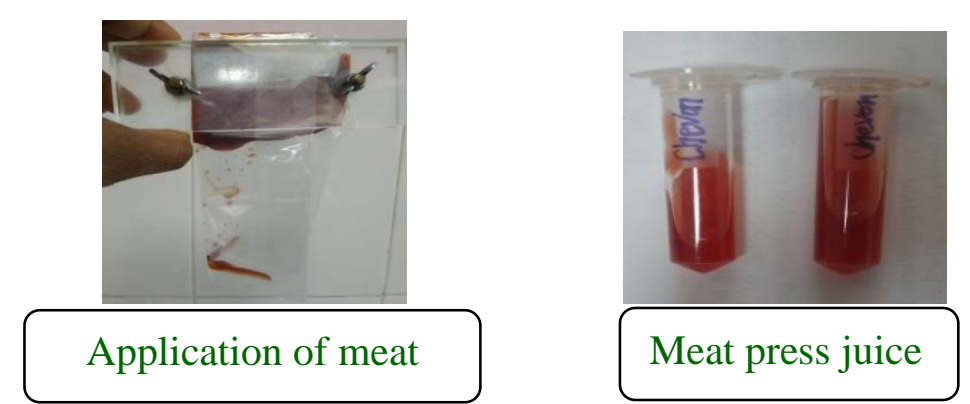

Fig.1 Collection of meat press juice from Chevon (Cheung et al., 2015)

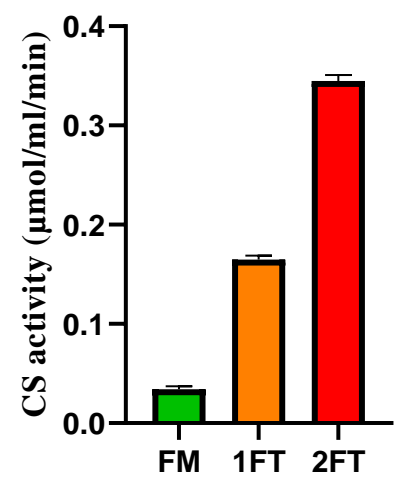

NO OF FREEZE-THAW CYCLE

Fig.2 Citrate synthase activity ( $\mu \mathrm{mol} / \mathrm{ml} / \mathrm{min}$ ) values of FM (Fresh meat),

1 FT $\left(1^{\text {st }}\right.$ Freeze-thaw cycle $)$ and 2 FT $\left(2^{\text {nd }}\right.$ Freeze-thaw cycle $)$ of chevon 
This might be due to mechanical damage to cell membranes by repeated melting and reformation of ice crystals during freezing and thawing in multiple freeze-thaw cycles (Aroeira et al., 2016). It weakens the protein matrix (protein oxidation) leading to increased toughness, loss in myofibrillar protein solubility (Benjakul and Bauer, 2000) and loss of water-binding capacity during repeated freezing and thawing. In addition, lipid oxidation stimulates changes in protein structures and in this manner manipulates WHC of the muscle (Davies, 2005). However, this phenomenon could be explained by a high rate of proteolysis, protein oxidation and the lower $\mathrm{pH}$ during repeated freeze-thaw cycles.

\section{Thawing loss}

The thawing loss (Mean \pm SE) of chevon was $11.15 \pm 0.62 \%$ after one freeze-thaw cycle, and increased $(\mathrm{P}<0.05)$ to $24.31 \pm 0.84 \%$ after $2^{\text {nd }}$ freeze-thaw cycle. The relatively high value of thawing loss might be due to the results of freeze denaturation, in which both water in the form of drip and other substances leak from the damaged cells during the process of freeze-thawing (Burgaard and Jorgensen, 2011). The majority of the water loss as drip contributed from the immobilized water in the myofibrillar proteins of the meat (Duun and Rustad, 2008). The findings of the present study were close to the values reported by Leygonie et al., (2012) in Ostrich M. iliofibularis, Katekhaye et al., (2012) in chevon longissmusdorsi, Xia et al., (2012) in porcine longissmusdorsi and Cai et al., (2014) in Japanese sea bass. All of them noticed increase in thawing loss with increase in number of freeze-thaw cycle.

\section{Total plate count (TPC)}

Total plate count values of chevon meat samples increased significantly $(\mathrm{P}<0.05)$ during repeated freezing and thawing. This might be due to cell damage, causing release of nutrients, making them more available to bacteria. Repeated freezing-thawing increases the time that the meat is at a temperature where bacteria can grow easily. The TPC values (Mean $\pm \mathrm{SE}$ ) of chevon in fresh, $1^{\text {st }} \mathrm{FT}$ and $2^{\text {nd }}$ FT were $4.82 \pm 0.17,5.61 \pm 0.22$ and6.19 $\pm 0.13 \log c f u / g$ (Table 2).The significant increased $(\mathrm{P}<0.05) \quad$ TPC value recorded for freeze-thawed meat could be due to the leakage of fluid during thawing, that is rich in nutrients required for microbial growth (Leygonie et al., 2012).

An increased TPC values with increase in freeze-thaw cycles count was observed in chicken thigh muscle by Bae et al., (2014). The result supports the findings of Katekhaye et al., (2012) for chevon who observed increased microbial load during different freeze-thaw cycles. In the present investigation, TPC value of all the samples was found to be (ranging from 4.82 to 6.19 $\log \mathrm{cfu} / \mathrm{g}$ ) within the acceptable meat safety limit (less than $7 \log \mathrm{cfu} / \mathrm{g}$ ). Although the degree of freshness or spoilage of meat is often evaluated by plate counts, it is known that spoilage is not the result of bacterial count per se but is caused by enzymatic activity and biochemical changes brought about by the growing microflora.

Citrate synthase activity increased during repeated freeze-thaw cycles of chevon and proved to be a suitable marker enzyme for the detection of temperature abuse during freezing and differentiation of fresh from frozen-thawed meat. Meat $\mathrm{pH}$ and $\mathrm{WHC}$ were decreased; however TBARS and thawing loss were increased: whereas, total plate count was increased with increase in number of freezethaw cycle. Increase in enzymatic activity was found well correlated with undesirable changes in meat quality during repeated freezing and thawing. 
Therefore, citrate synthase enzymatic assay could be used as biomarker to differentiate fresh from frozen-thawed chevon.

\section{Acknowledgement}

The authors acknowledge the grant provided by ICAR-IVRI, Izatnagar for conducting the research work. We are also thankful to Director, JD (R), ICAR-IVRI for providing necessary infrastructural facilities to perform the study.

\section{References}

Ali, S., Zhang, W., Rajput, N., Khan, M.A., Li, C.B. and Zhou, G.H. 2015.Effect of multiple freeze-thaw cycles on the quality of chicken breast meat. Food Chem., 173: 808-814.

Aroeira, C.N., Torres Filho, R.A., Fontes, P.R., Gomide, L.A.M., Ramos, A.L., Ladeira, M.M. and Ramos, E.M., 2016. Freezing, thawing and aging effects on beef tenderness from Bosindicus and Bostaurus cattle. Meat science, 116, pp.118-125.

Bae, Y.S., Lee, J.C., Jung, S., Kim, H.J., Jeon, S.Y., Park, D.H., Lee, S.K. and Jo, C., 2014. Differentiation of deboned fresh chicken thigh meat from the frozen-thawed one processed with different deboning conditions. Korean journal for food science of animal resources, 34(1), p.73.

Ballin, N. Z. and Lametsch, R. 2008.Analytical methods for authentication of fresh vs. thawed meat - A review.Meat sci.,80: 151158.

Benjakul, S. and Bauer, F., 2000. Physicochemical and enzymatic changes of cod muscle proteins subjected to different freeze-thaw cycles. Journal of the Science of Food and Agriculture, 80(8), pp.11431150.

Benjakul, S. and Bauer, F., 2001. Biochemical and physicochemical changes in catfish (SilurusglanisLinne) muscle as influenced by different freeze-thaw cycles. Food Chemistry, 72(2), pp.207-217.

Burgaard, M.G. and Jørgensen, B.M., 2011. Effect of frozen storage temperature on qualityrelated changes in rainbow trout (Oncorhynchusmykiss). Journal of aquatic food product technology, 20(1), pp.53-63.

Cai, L., Wu, X., Li, X., Zhong, K., Li, Y. and Li, J., 2014. Effects of different freezing treatments on physicochemical responses and microbial characteristics of Japanese sea bass (Lateolabrax japonicas) fillets during refrigerated storage. LWT-Food Science and Technology,59(1), pp.122129.

Chen, T. H., Zhu, Y. P., Han, M. Y., Wang, P., Wei, R., Xu, X. L. and Zhou, G. H. 2017. Classification of chicken muscle with different freeze-thaw cycles using impedance and physicochemical properties. J. food eng., 196: 94-100.

Cheng, S., Wang, X., Li, R., Yang, H., Wang, H., Wang, H. and Tan, M. 2019. Influence of multiple freeze-thaw cycles on quality characteristics of beef semimembranous muscle: With emphasis on water status and distribution by LF-NMR and MRI. Meat sci., 147: 44-52.

Cheung, T. C., Cheng, E. C. C., Chan, H. Y., Tong, S. K., Chan, P. K., Lee, F. W., Wong, Y. C., and Sin, D. W. M. 2015. Development of a Validated Database for the Authentication of Fresh/Chilled and Frozen Pork Using $\beta$-Hydroxylacyl-CoADehydrogenases (HADH) Assay. Int. j.food properties, 18(1): 73-80.

Davies, M.J., 2005. The oxidative environment and protein damage. Biochimicaet BiophysicaActa (BBA)-Proteins and Proteomics, 1703(2), pp.93-109.

Duun, A.S. and Rustad, T., 2008. Quality of superchilled vacuum packed Atlantic salmon (Salmosalar) fillets stored at- 1.4 and $\quad-3.6 \mathrm{C}$. Food Chemistry, 106(1), pp.122-131.

Hamm, R. 1979. Delocalization of Mitochondrial Enzymes During Freezing and Thawing of Skeletal Muscle. Adv. Chem. Ser., 180: 191-204.

Hamm, R. and Gottesmann, P. 1984. Release of mitochondrial enzymes by freezing and thawing of meat: structural and analytical aspects. Proceedings of European Meat Research Work Meeting, 3: 152-155. 
Hernández, P., Navarro, J.L. and Toldrá, F., 1999.Effect of frozen storage on lipids and lipolytic activities in the longissimusdorsi muscle of the pig. Zeitschriftfür Lebensmitteluntersuchung und-Forschung A, 208(2), pp.110-115.

Katekhaye, A. F. 2012. Influence of freeze-thaw cycle abuse on quality attributes of chevon during storage. M.V.Sc. Thesis submitted to MAFSU, Nagpur.

Leygonie, C., Britz, T. J., and Hoffman, L. C. 2011.Oxidative stability of previously frozen ostrich M. iliofibularis packaged under different modified atmospheric conditions.Int. J. Food Sci. Tech., 46: 1171-1178.

Leygonie, C., Britz, T.J. and Hoffman, L.C. 2012. Impact of freezing and thawing on the quality of meat: Review. Meat Sci., 91: 9398.

Li, C., Liu, D., Zhou, G., Xu, X., Qi, J., Shi, P. and Xia, T. 2012. Meat quality and cooking attributes of thawed pork with different low field NMR T21. Meat sci., 92(2): 79-83.

Pipek, P., Brychta, J., Petrova, M., Šimoniova, A. and Rohlik, B.A. 2010, Jakrozlišitzmrazene/rozmraženemaso od čerstveho: Maso.,21(4): 43-48.

Qi, J., Li, C., Chen, Y., Gao, F., Xu, X. and Zhou, G. 2012. Changes in meat quality of ovine longissimusdorsi muscle in response to repeated freeze and thaw. Meat sci., 92(4): 619-626.

Saldanha, T. and Bragagnolo, N., 2008. Relation between types of packaging, frozen storage and grilling on cholesterol and fatty acids oxidation in Atlantic hake fillets (Merlucciushubbsi). Food Chemistry, 106(2), pp.619-627.
Savell, J.W., Mueller, S.L. and Baird, B.E., 2005. The chilling of carcasses. Meat science, 70(3), pp.449-459.

Simoniova. A., Rohlík, B. A., Skorpilova. T., Petrova.M.andPipek. 2013. Differentiation Between Fresh and ThawedChicken Meats. Czech J. Food Sci., 31(2): 108- 115

Tarladgis, B.G., Watts, B.M., Younathan, M.T. and Dugan Jr, L., 1960. A distillation method for the quantitative determination of malonaldehyde in rancid foods. Journal of the American Oil Chemists' Society, 37(1), pp.44-48.

Trout, E. S., Hunt , M. C., Johnson, D. E., Clauss, J. R., Kastner, C. L., Kropf, D. H. and Storda, S. 1992. Chemical, physical and chemical characterization of ground beef containing 5 to 10 percent fat. J. Food Sci., 57(1): 25-29.

Vieira, C., Diaz, M.T., Martínez, B. and GarcíaCachán, M.D., 2009.Effect of frozen storage conditions (temperature and length of storage) on microbiological and sensory quality of rustic crossbred beef at different states of ageing. Meat Science, 83(3), pp.398-404.

Xia, X., Kong, B., Liu, J., Diao, X. and Liu, Q., 2012. Influence of different thawing methods on physicochemical changes and protein oxidation of porcine longissimus muscle. LWT-Food Science and Technology, 46(1), pp.280-286.

Xia, X., Kong, B., Liu, Q. and Liu, J., 2009.Physicochemical change and protein oxidation in porcine longissimusdorsi as influenced by different freeze-thaw cycles. Meat science, 83(2), pp.239-245.

\section{How to cite this article:}

Gowtham Prasad Bomminayuni, Sanjod Kumar Mendiratta, Suman Talukder, Sagar Chand, Rohit Kumar Jaiswal and Vandita Mishra. 2020. Differentiation of Fresh from Frozen Thawed Chevon by Citrate Synthase Enzymatic Assay. Int.J.Curr.Microbiol.App.Sci. 9(06): 1330-1338. doi: https://doi.org/10.20546/ijcmas.2020.906.165 